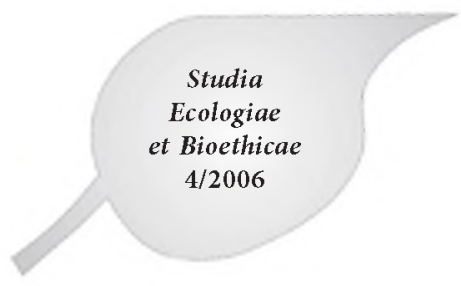

\title{
Droga do świadomości ekologicznej
}

Termin świadomość ekologiczna jest ostatnio często używany i stał się modny. Podłożem świadomości ekologicznej jest wiedza zdobyta w szkole i środowisku lokalnym (Olaczek, 1999, s. 250). Poglądy, przekonania i wzorce zachowań, jakie reprezentuje jednostka, zależą od środowiska, w którym przebywa. Wielkie znaczenie ma presja grupy, do której się należy. Samo słowo świadomość oznacza najwyższy poziom rozwoju psychicznego, charakterystyczny dla człowieka, jego przytomność i rozsądek. Świadomość w pełni ukształtowana decyduje o zachowaniu człowieka. Jeśli dodamy przymiotnik ekologiczny to uzyskamy termin, którego treścią są: świadomość prawa człowieka do środowiska, świadomość zagrożeń, poczucie własnej odpowiedzialności za jego stan oraz przekonanie o konieczności ochrony przyrody. Aby świadomość ekologiczna stała się świadomością społeczną, musi wynikać ze stałego dopływu informacji i przekazywaniu tradycji ze środowiska lokalnego. Dla dziecka w wieku przedszkolnym i szkolnym środowisko lokalne to: podwórko, osiedle, szkoła, jak również to, co się nie zmieściło w najbliższym otoczeniu, na własnym osiedlu, a jest potrzebne do prawidłowego rozwoju młodego osobnika. Dziecko spędza czas na terenie dla niego najbliższym i dlatego poziom przekazywanej wiedzy, zwyczaje, tradycje, poglądy środowiska lokalnego są dla niego bardzo ważne. Środowisko miejsca zamieszkania stanowi świat dla małego dziecka.

T. Pilch (1995, s. 156) uważa, że „środowisko lokalne oprócz zbiorowości lokalnej zamieszkującej niewielki względnie zamknięty obszar, oznacza również cały system instytucji służących organizacji życia zbiorowego, takich jak kościół, szkoła, instytucje usługowe, urządzenia socjalne lub rekreacyjne oraz mechanizmy regulujące zachowania jednostkowe i stosunki międzyludzkie, a więc obyczajowość i normy moralne, autorytety i wzory zachowan̂". Szczególna wspólnota łącząca i integrująca pewne społeczności nie musi być związana z zamieszkiwaniem na wspólnym terenie, ale może opierać się na podzielaniu tych samych wartości, symboli i respektowania zasad wzajemnego porozumienia.

F. Znaniecki $(1928$, s. 3) wskazuje na środowisko rzeczywiste grup społecznych jako miejsce zdobywania nowych doświadczeń oraz tworzenia zwyczajów, obrzędów i tradycji. Natomiast w ujęciu H. Radlińskiej (1961. s. 366) środowisko 
życia to zespół warunków, wśród których bytuje jednostka. Przyblizając pojęcie środowiska lokalnego R. Wroczyński (1985, s. 78) zwraca uwagę na „elementy otaczającej struktury przyrodniczej, społecznej i kulturalnej, które działają na jednostkę". Przytoczone przykłady wyraźnie wskazują, że rola środowiska lokalnego i jego funkcja wychowawcza zajmują ważne miejsce w kształtowaniu poglądów jednostki. Środowisko jest także wskazywane przez filozofię ekologiczną jako miejsce bytowania człowieka. R. Wroczyński podkreślana także wielowarstwowość środowiska. Elementy środowiska: przyrodnicze, kulturowe, społeczne i techniczne nieustannie podlegają zmianom. Na potrzeby ekofilozofii wiedzę o zmianach w środowiskach: naturalnym i technicznym przejmuje się niemal w całości ze światopoglądu naukowego, konkretnie z metodologii nauk przyrodniczych. Wiedzy o bieżących zmianach w środowisku społecznym dostarczają analizy socjologiczne (W. H. Zylbertal, 2000, s.8). Z wymienionych środowisk zdaniem W. H. Zylbertala „środowisko kulturowe jako czynnik najsilniej kształtujący ludzkie postawy i motywacje, jest tu nadrzędne wobec wszelkich innych typów środowiska”.

Kształtowanie u dziecka obrazu świata zależy od wiedzy, która zostanie mu przekazana od chwili narodzin. Postawa, jaka będzie reprezentowana wobec świata, jest odbiciem działań podejmowanych przez rodzinę, szkołę i wszystkich przedstawicieli środowiska lokalnego. Ponieważ najważniejsze są pierwsze kontakty z przyrodą, warto zwrócić uwagę na wychowywanie dzieci w szacunku do niej, wdrażanie do segregowania odpadów, oszczędzania zużycia wody i energii. Kluczowym aspektem bezpośredniego kontaktu z przyrodą jest poznawanie jej wszystkimi zmysłami. Spacery z rodzicami, podczas których dzieci rozpoznają drzewa w parku i różne rośliny na klombie, są bardzo istotnym elementem wychowawczym. Nie tylko mogą stać się wzorem, jak należy zagospodarować czas wolny, ale także ukierunkowują zainteresowania i umożliwiają zdobywanie nowych wiadomości. Ważne jest to, aby dzieci zrozumiały, że otaczający świat, a przede wszystkim przyroda, nie potrzebowałaby ratunku, gdyby nie nadmierna ingerencja człowieka.

Nasze działania są wynikiem naszego sposobu odczytywania wszechświata (Skolimowski, 1993, s. 20). Wartości reprezentowane przez poszczególne jednostki są wyznacznikiem sposobu pojmowania ich. Dzieci naśladują dorosłych i często bezkrytycznie przyjmuję reprezentowane przez nich wzorce. Jeśli środowisko rodzinne, w którym dziecko stawia pierwsze kroki, ma pozytywny stosunek do przyrody, a sprawa środowiska nie jest obojętna tworzą się pewne standardy postępowania, które jako wartości wyniesione z dzieciństwa pozostają na całe życie. 


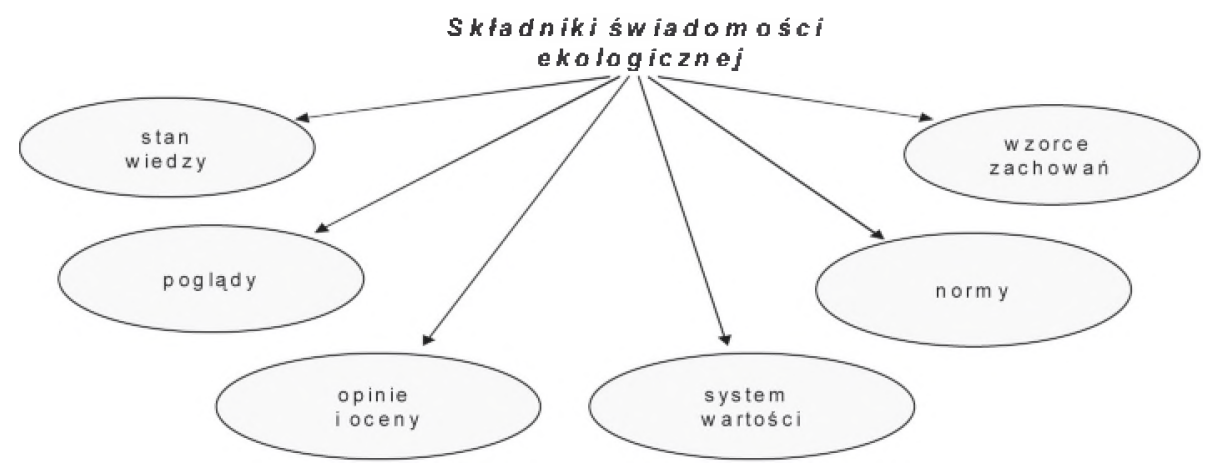

Ryc. 1. Składniki rozwijające świadomość ekologiczną

Aktualnie narasta konieczność przewartościowania postaw człowieka względem przyrody. Decydującą rolę w tym zakresie może spełniać spójny system edukacji i wychowania środowiskowego dzieci i młodzieży. Edukacja kształcąca postawy i wartości powinna być akceptowana i realizowana przez nauczycieli, rodziców oraz wychowawców i instruktorów zajęć pozalekcyjnych. Wspomaganie działań szkoły przez zaangażowanie wszystkich instytucji środowiska lokalnego rozszerza możliwości oddziaływania wychowawczego dzięki wzmocnieniu poprzez atrakcyjne zajęcia, pracę w terenie, zakup nagród, pomocy dydaktycznych i okazów naturalnych.

Rozwijanie świadomości ekologicznej [ryc.1] następuje poprzez wyposażenie człowieka w wiedzę społeczną i ekologiczną, w system wartości i ich normatywne odpowiedniki. Istotne jest kształtowanie postawy ekologicznej, rozumianej jako rozwinięte poczucie więzi ze światem przyrody i jego częściami, gotowość do jego obrony i ochrony oraz podjęcia konkretnych działań. Rola edukacji przyrodniczej polega na dostarczaniu katalogu wartości i norm, odpowiednio kształtujących motywacje, postawy i zachowania.

Uświadamianie sobie odpowiedzialności człowieka za istnienie i dalsze trwanie życia na Ziemi wpłynęło na inną interpretację nauki, kultury, filozofii a nawet religii w kształtowaniu poglądu na świat żywych istot.

Właściwa i skuteczna ochrona środowiska naturalnego uzależniona jest od poziomu wiedzy społeczeństwa i od preferowanych stylów życia, które podlegają ciągłym zmianom, przede wszystkim dzięki edukacji, prowadzącej do upowszechnienia wzorca kultury ekologicznej. Należy przy tym pamiętać, że ekologia jako dziedzina biologii badająca wzajemne relacje między organizmami a środowiskiem, w którym żyją, wymusza holistyczne podejście do zjawisk zachodzących w przyrodzie. 
Postrzeganie zależności w przyrodzie i kontaktów człowiek - środowisko, uzależnione jest od posiadanych przekonań i wpływa na funkcjonowanie jednostki w społeczeństwie.

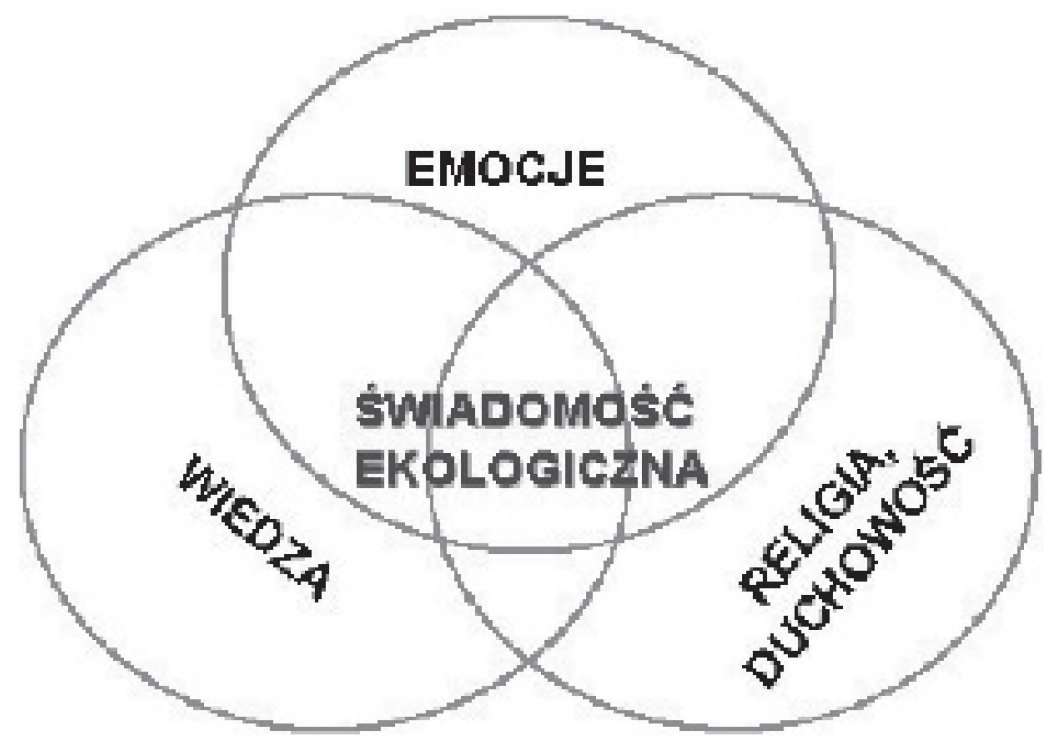

Ryc. 2. Elementy wpływające na kształtowanie świadomości ekologicznej (opracowanie własne)

Kontakt z naturą wyzwala pozytywne emocje, jednocześnie jest bodźcem wzmacniającym percepcję. Emocje te wpływają na kształtowanie wartości i postaw proekologicznych, ale wiedza i emocje to zbyt mało, aby w pełni ukształtować świadomość ekologiczną, która jest czynnikiem warunkującym nasze zachowania w przyszłości [ryc. 2]. Posiadanie świadomości ekologicznej to zdaniem H. Skolimowskiego (1993, s. 52) uświadomienie sobie, że wraz z nią człowiek należy do jednej całości. Zjawiska naturalne od wieków miały dla człowieka znaczenie mistyczne, uduchowione. Moc natury skłaniała ludzi do oddawania jej czci a w składniki przyrody nieożywionej człowiek tchnął cechy istot żywych. Wiara w życiodajną siłę natury i przekonanie o sile łączącej człowieka z przyrodą przetrwały tysiące lat. Poglądy te stały się podstawą wyodrębnienia się wielkich religii świata. Wiara i religia silnie oddziałują na osobowość dziecka i otaczają je od urodzenia. Są nośnikiem wartości, jakie spontanicznie do niego docierają. Jeśli wyrasta w środowisku, w którym prezentowane są pozytywne postawy wobec przyrody, z dużym prawdopodobieństwem można stwierdzić, że wyzwolą nowe wartości proekologiczne i utrwalą je. Wieloletnie kształcenie i wychowanie w duchu rozwoju zrównoważonego powinno skutkować postawami przesiąkniętymi 
ideami proekologicznymi. Po latach takiego oddziaływania na postawy młodego pokolenia, ich zachowania proekologiczne na rzecz trwałego i zrównoważonego rozwoju podejmowane są spontanicznie jako własne, z pełnym przekonaniem o słuszności.

We wrześniu 2005 roku przeprowadzone zostały pilotażowe badania wśród mieszkańców dzielnicy Wola w Warszawie w celu poznania poglądów na temat ochrony środowiska oraz świadomości ekologicznej społeczności lokalnej.

Do końca września badaniami objęto 481 osób. Wykonano je metodą sondażu diagnostycznego $\mathrm{z}$ wykorzystaniem ankiety.

$\mathrm{Z}$ analizy uzyskanych danych wynika, że 75\% badanych uważa, że zainteresowanie ochroną środowiska w ciągu ostatnich 10 lat wzrosło.

Pozytywne zmiany w ocenie stanu środowiska [wykres 1] wskazuje ponad połowa badanych $(51,35 \%)$, a $8 \%$ uważa, że stan środowiska zdecydowanie się zmienil.

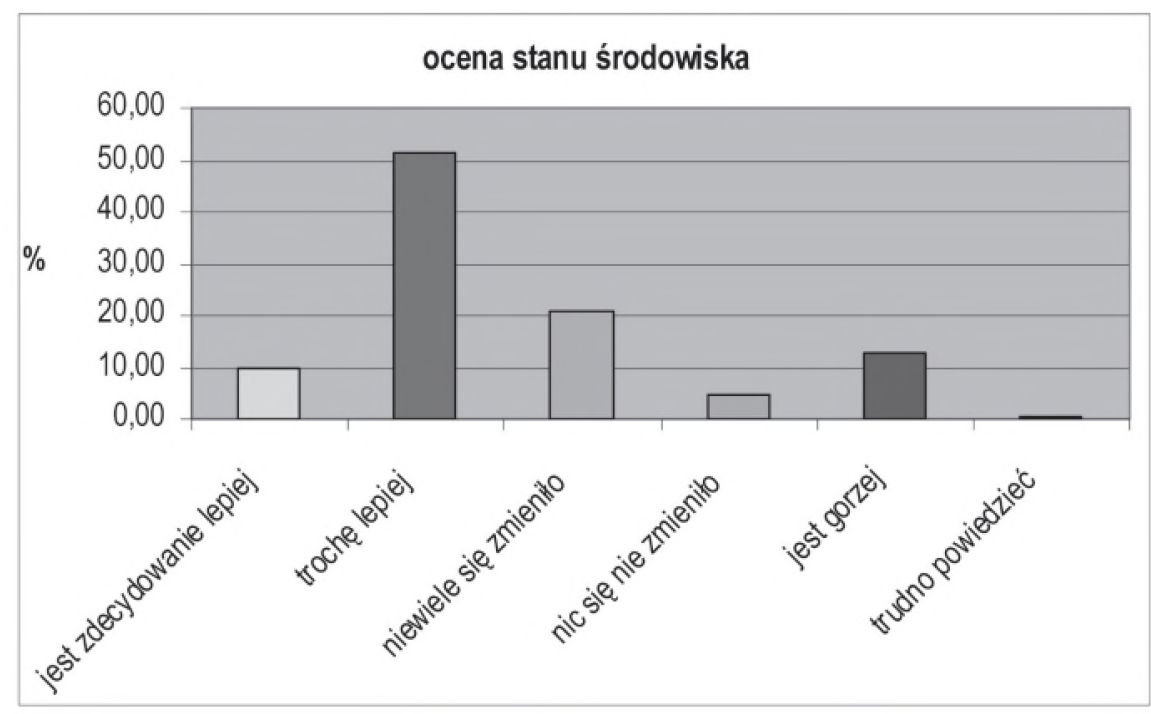

Wykres 1. Ocena stanu środowiska w ostatnich 10 latach?

Ponad $48 \%$ badanych [wykres 2] uważa, że pozytywne nastawienie do ochrony środowiska kształtowane jest w szkole, a $20 \%$ dostrzega tu rolę studiów wyższych. Zdziwienie budzi fakt, że tylko $27 \%$ zauważa dużą rolę domu rodzinnego w kształtowaniu pozytywnego nastawienia do ochrony środowiska a $21 \%$ wpływ poglądów prezentowanych przez środowisko lokalne. Wpływ informacji przekazywanych przez media wskazuje niewiele ponad $20 \%$ respondentów. Wpływ religii na pozytywne nastawienie do ochrony środowiska zauważa ponad 16\% ankietowanych. 


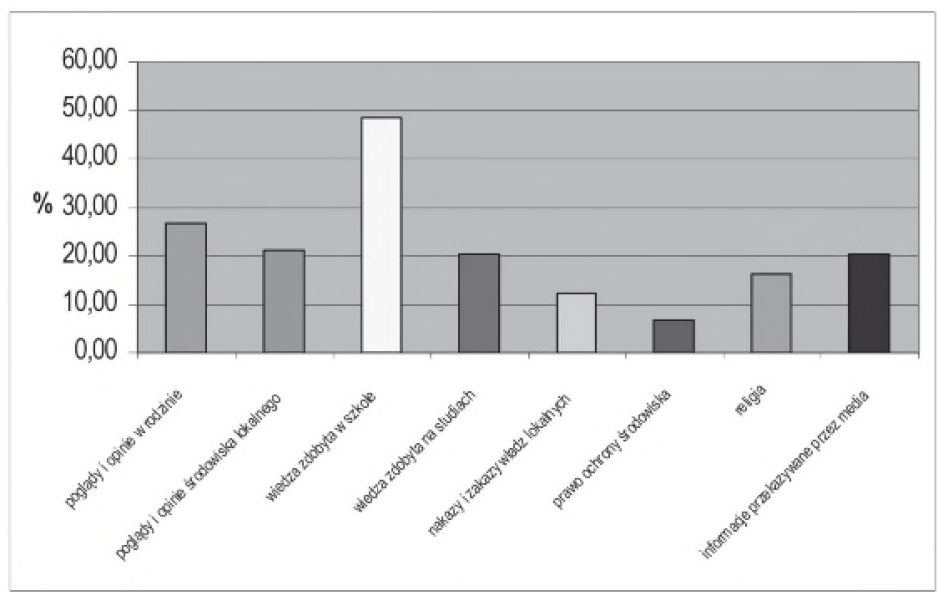

Wykres 2. Czynniki wpływające na pozytywne nastawienie do ochrony środowiska

Procenty nie sumują się do 100, ponieważ badani mogli wybrać więcej niż jedną odpowiedź. Wszyscy respondenci zgodnie stwierdzili, że podejmują działania proekologiczna [wykres 3]. Najczęściej wymieniają ograniczenia zużycia energii $(90 \%)$ i wody $(67 \%)$. Badani wskazują na wielką rolę zbierania surowców wtórnych - 63\%, ale już segregowanie odpadów w swoich gospodarstwach domowych deklaruje $41 \%$. Najmniejszym zainteresowaniem cieszą się spotykania i wykłady na temat ochrony środowiska (2,5\%), wspólpraca z organizacjami pozarządowymi - ekologicznymi $(3,5 \%)$ oraz organizowanie i udział w akcjach sąsiedzkich w celu zazielenienia osiedla i wykonywania prac porządkowych np. w lasach (10\%).

Blisko 37\% badanych dokonując zakupów zwraca uwagę na rodzaj opakowań i unika opakowań jednorazowych. Co trzeci badany racjonalnie używa detergentów.

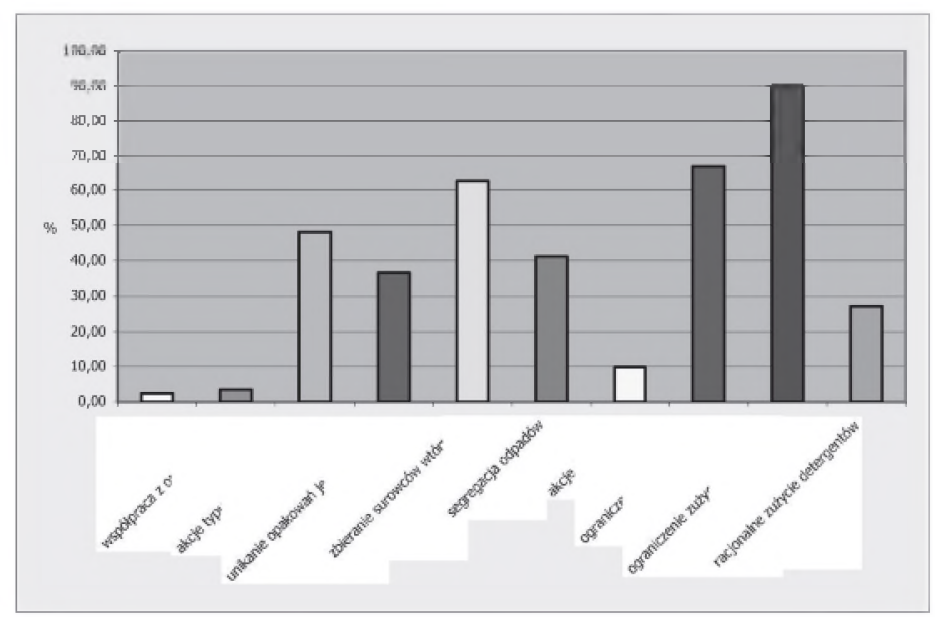

Wykres 3. Podejmowane działania proekologiczne 
Procenty nie sumują się do 100, ponieważ badani mogli wybrać więcej niż jedną odpowiedź. Badani podawali podmioty [wykres 4], które ich zdaniem powinny podejmować działania wpływające na stan środowiska w miejscu zamieszkania. Blisko $62 \%$ respondentów uważa, że o stan środowiska powinny dbać władze lokalne (samorządowe), a 37\% wskazuje mieszkańców, jako tych, których działania wpływają na stan środowiska w miejscu zamieszkania. Zaskakujące jest to, że ponad 53\% mieszkańców widzi szkołę jako instytucję, która powinna w najbliższym otoczeniu podejmować działania wpływające na stan środowiska.

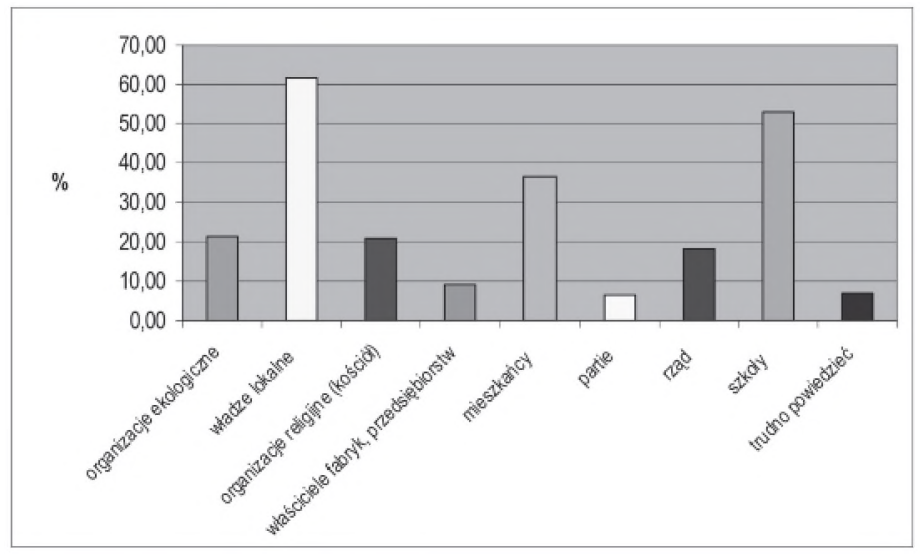

Wykres 4. Podmioty, które powinny podejmować działania proekologiczne

Procenty nie sumują się do 100 , ponieważ badani mogli wybrać więcej niż jedną odpowiedź. Bardzo duża grupa (68\%) stwierdziła, że świadomość zagrożeń środowiska w niewielkim stopniu wpływa na codzienne działania lub w ogóle nie ma na nic wpływu [wykres 5].

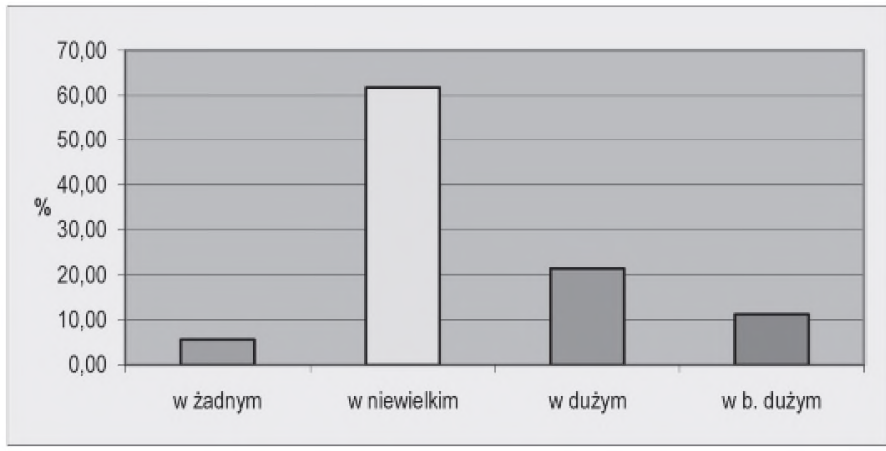

Wykres 5. Wpływ świadomości na podejmowanie codziennych czynności 
Tylko $\mathbf{u}^{1}{ }_{3}$ badanych posiadana świadomość ekologiczna wpływa na podejmowanie czynności dnia codziennego. Aż $67 \%$ respondentów [wykres 6] nie rozmawia (7\%) lub bardzo rzadko $(60 \%)$ z rodziną i znajomymi na temat ochrony środowiska. Co trzeci badany prowadzi rozmowy z dziećmi i znajomymi na temat zagrożeń i ochrony środowiska.

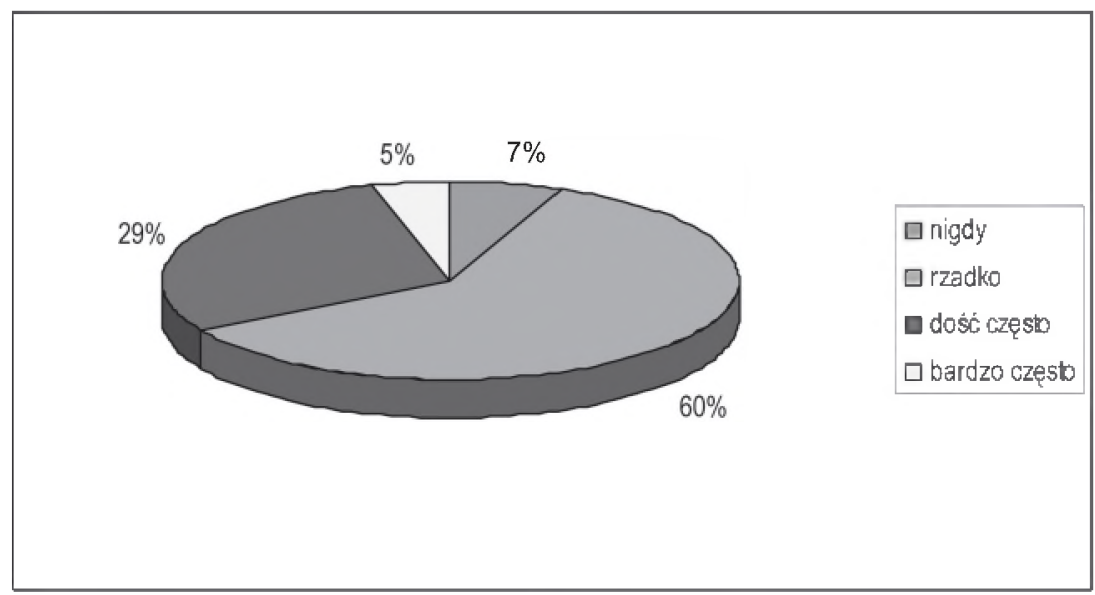

Wykres 6. Częstotliwość rozmów na temat zagrożeń środowiska

Po dokonaniu analizy przedstawionego materiału można stwierdzić, że świadomość ekologiczna mieszkańców wolskich osiedli nie jest najwyższa. Zauważyli oni, że stan środowiska podlega zmianom i wzrasta zainteresowanie jego ochroną, natomiast zbyt dużo mieszkańców przerzuca kształtowanie postaw proekologicznych na szkołę i uczelnię nie dostrzegając wielkiej roli rodziny. W polskim szkolnictwie podstawowym, gimnazjalnym i ponadgimnazjalnym nie ma obowiązku systemowego kształcenia ekologicznego. Wprowadzone ścieżki międzyprzedmiotowe nie gwarantują ani odpowiedniego poziomu wiedzy, ani prawidłowego jej przekazania. Szybko więc będą widoczne efekty zaniedbań edukacji ekologicznej. Aby nie dopuścić do tych zaniedbań należy świadomość ekologiczną wpisać w wychowanie i rozwój młodego człowieka. Do mieszkańców powinna docierać rzetelna informacja o stanie lokalnego środowiska. Wiedzę na temat zagrożeń i ochrony środowiska musimy przekazywać w każdym wieku. Badana społeczność jest przekonana, że w miejscu zamieszkania problemy ochrony środowiska powinna rozwiązywać władza samorządowa - lokalna. Zbyt mała grupa postrzega konieczność zmiany swojego postępowania i rozumie, że każdy indywidualnie jest odpowiedzialny za stan środowiska, w którym zamieszkuje. Zbyt rzadko tematy związane z ochroną środowiska są poruszane w codziennych rozmowach, z czego można wyciągnąć wniosek, że problem ten nie jest ważny dla mieszkań- 
ców. Wskazują oni również ogromną rolę szkoły w kształtowaniu świadomości ekologicznej. Musimy jednak pamiętać, że pierwszy etap wychowania odbywa się w rodzinie i jej wplyw na postawy małego dziecka jest olbrzymi. Dlatego warto upowszechnić informację, że to rodzina powinna przekazywać podstawy wiedzy w tym zakresie. Ponieważ braki świadomości i kultury ekologicznej są widoczne w całym społeczeństwie bez względu na wiek, edukacja ekologiczna nie powinna być prowadzona jedynie w szkole, ale stanowić nierozerwalną całość procesu wychowawczego rozpoczętego w chwili narodzin.

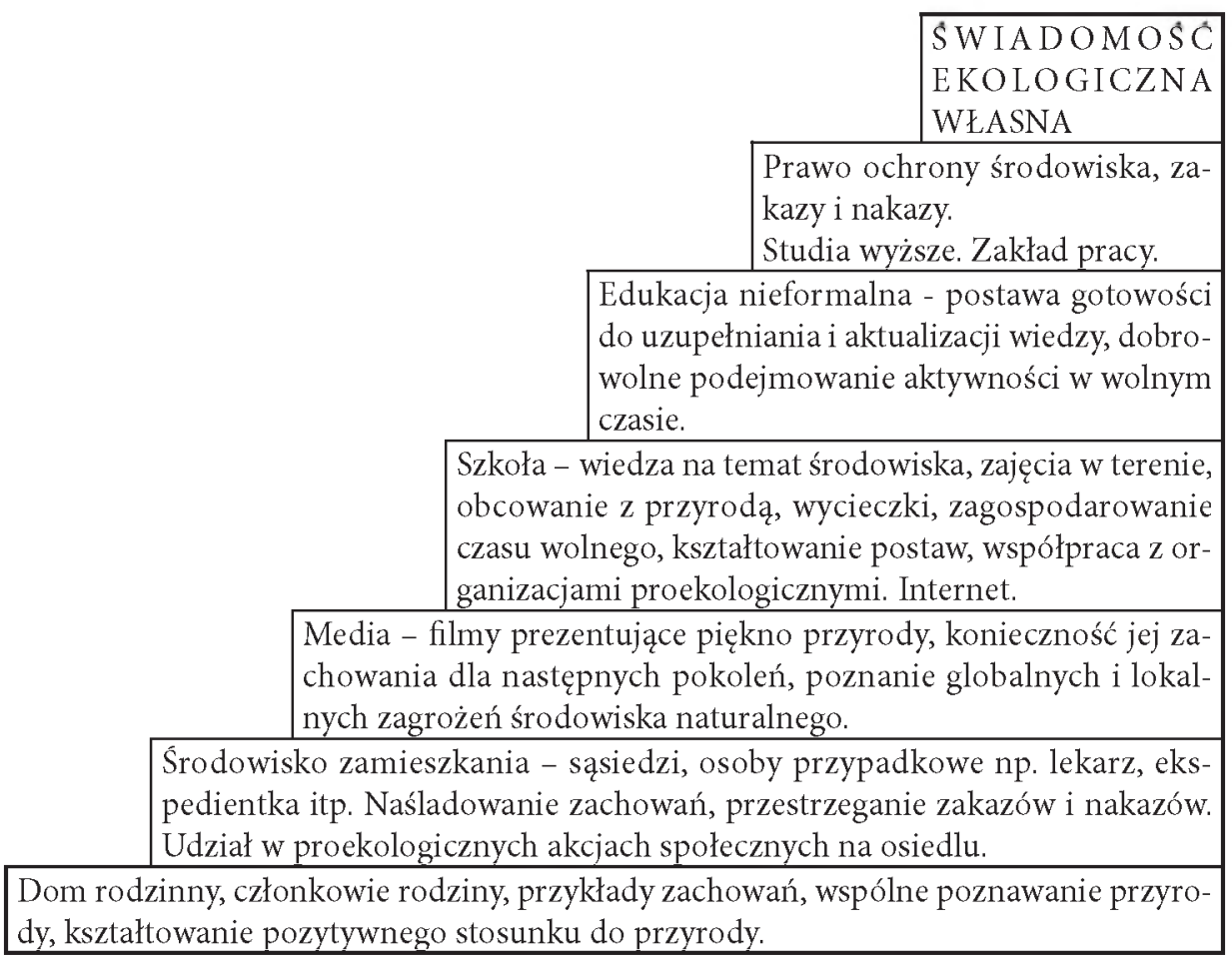

Ryc. 3. Piramida kształtowania świadomości ekologicznej

Pierwsze kroki odbywać się muszą we własnej rodzinie, a następnie w środowisku lokalnym [ryc. 3]. Małe dzieci chętnie podejmują działania wymagające aktywności. Z wielkim zaangażowaniem wraz z rodzicami dokonują pierwszych obserwacji przyrody. Od najwcześniejszych lat kształtują się wzorce kulturowe. Dlatego ogromny wpływ na kształtowanie się świadomości ekologicznej warunkującej zachowania dzieci ma rodzina, sąsiedzi i najbliżsi znajomi. Determinowane są one także postawami rówieśników, kolegów z podwórka i ze szkoły. System kształcenia uczniów w zakresie ochrony środowiska na wszystkich 
etapach edukacyjnych zaczynając od wychowania przedszkolnego dąży do wykształcenia świadomości ekologicznej poprzez:

- budzenie szacunku do przyrody,

- poznanie zagrożeń lokalnego środowiska przyrodniczego,

- uwrażliwienie na problemy środowiska,

- poznanie zależności między działaniem człowieka i środowiskiem,

- kształtowanie poczucia odpowiedzialności za stan środowiska,

- poznanie zależności występujących w środowisku naturalnym,

- wykształcenie umiejętności obserwowania zjawisk przyrodniczych.

Uzupełnieniem wzbogacającym efekty edukacji ekologicznej prowadzonej w szkole są pozaszkolne zajęcia i tematyka proekologiczna realizowana przez: najbliższe otoczenie, media, organizacje ekologiczne, organizacje społeczne, ośrodki edukacyjne i oświatowe.

Działania podejmowane przez szkołę i inne ośrodki, mimo trafnych założeń nie zaspakajają oczekiwań. Edukacja ekologiczna nie jest skuteczna (Frątczak, 1995, s. 45).

Nauczyciele sygnalizują, że coraz większa grupa uczniów nie jest zainteresowana nauką szkolną. Należy przypuszczać, że niska świadomość ekologiczna łączy się z niechęcią do nauki i niskim poziomem wiedzy przyrodniczej. Małe jest prawdopodobieństwo, aby uczniowie, którzy nie wynieśli z domu rodzinnego kultu nauki, ciekawości świata i szacunku dla wiedzy, bez dodatkowych bodźców z wielkim entuzjazmem podejmowali działania na rzecz środowiska przyrodniczego. Edukacja środowiskowa daje możliwość uaktywnienia młodego pokolenia. Każdy może znaleźć miejsce dla siebie i osiągnąć sukces. Działalność na rzecz środowiska lokalnego integruje grupę, a atrakcyjność zadań zależy od pomysłowości nauczyciela i jego aktywności w środowisku. Nawiązanie współpracy z samorządem lokalnym, organizacjami pozarządowymi jest dobrym sposobem na wprowadzenie dodatkowych atrakcyjnych bodźców dla uczniów. Samorząd lokalny chętnie podejmuje współpracę ze szkołami, finansuje nagrody w konkursach ekologicznych, wyposaża w pomoce dydaktyczne pracownie przyrodnicze i wzbogaca biblioteki w nowości wydawnicze, albumy przyrodnicze i encyklopedie. Nauczyciele wspomagani finansowo przez urzędy gminne organizują konkursy fotograficzne, plastyczne i olimpiady wiedzy. W twórczych pracach doskonale uwidacznia się świadomość ekologiczna młodych twórców. Praca w terenie, organizowanie przedstawień o tematyce ekologicznej, projektowanie i wykonywanie plakatów propagujących akcje dla środowiska lokalnego przybliżają tematykę przyrodniczą, nawet tym, dla których nauka szkolna nie jest priorytetem. Efekty tej edukacji następują bardzo wolno, ale aby ukształtować świadomość ekologiczną podejmowane działania powinny być systematyczne. Należy:

- wzbogacić programy nauczania o treści ekologiczne, 
- zintegrować realizację edukacji ekologicznej z rzeczywistością,

- zwiększyć ilość kół zainteresowań związanych z edukacja środowiskową,

- rozszerzyć zakres edukacji pozaszkolnej,

- zwiększyć ilość krótkich komunikatów, spotów ekologicznych w mediach,

- objąć edukacją dorosłych, społeczności lokalne.

Aby zachować środowisko naturalne dla przyszłych pokoleń musi być w społeczeństwie ukształtowana świadomość ekologiczna na odpowiednim poziomie. Poczucia odpowiedzialności za środowisko nas otaczające nie osiągniemy bez edukacji środowiskowej, społecznej związanej ze wzmocnieniem więzi społecznych i więzi ze środowiskiem. Podnoszenie świadomości wydaje się we współczesnym świecie sprawą najwyższej wagi, wymagającą wielu działań ze strony władz administracyjnych i samorządowych, systemu oświaty i całego społeczeństwa. Działanie edukacyjne powinny zmierzać do przekonania społeczności lokalnej o równorzędności celów społecznych i ekologicznych oraz o potrzebie racjonalnego gospodarowania środowiskiem przyrodniczym (Dubel, 2000, s. 33).

Skutki działalności człowieka, ingerencji w środowisko naturalne i jego eksploatacja wymaga zintensyfikowanie działań na rzecz środowiska. Niezbędnym elementem współczesnej edukacji jest odpowiednie przygotowanie uczniów do podejmowania racjonalnych działań służących ochronie przyrody i poprawie stanu środowiska (Cichy, 2003, s. 33). Podniesienie świadomości ekologicznej, która w konsekwencji zaowocuje zmianą postaw, tworzeniem nowych wartości oraz zmianą przyzwyczajeń i stylu życia wymaga daleko posuniętej współpracy i synchronizacji działań edukacyjnych i informacyjnych wielu instytucji. Efekty zależą nie tylko od szkoły ale także od klimatu wokół zagadnień związanych z problematyką środowiska przyrodniczego, jego ochrony tworzonych przez przedstawicieli różnych środowisk naukowych, kulturalnych, politycznych i gospodarczych. Bardzo ważną rolę w kształtowaniu świadomości ekologicznej poza edukacją odgrywają konkretne działania i decyzje gospodarcze podejmowane na rzecz środowiska, szczególnie silnie, gdy efekty decyzji gospodarczych są widoczne i korzystne dla otoczenia.

\section{Bibliografia}

Cichy D., 2003: Szkoła wobec wyznań edukacji biologicznej i środowiskowej w XXI wieku. Wyd. IBE, Warszawa.

Dubel K., Edukacja społeczności wiejskiej na potrzeby zrównoważonego rozwoju, [w:] Zeszyty naukowe nr 24, PAN, Warszawa, $2000 \mathrm{r}$.

Frątczak J., 1995: Świadomość ekologiczna dzieci, młodzieży i dorosłych w aspekcie edukacji szkolnej i nieszkolnej. Wydawnictwo Uczelniane WSP, Bydgoszcz.

Pilch T., 1993: Środowisko lokalne - struktura, funkcje, przemiany, [w:] Pedagogika społeczna, Pilch T., Lepalczyk I., Uniwersytet Warszawski. 
Olaczek R., 1999: Ochrona przyrody i środowiska. WSiP, Warszawa.

Radlińska H., 1961: Pedagogika społeczna. Zakład Narodowy im. Ossolińskich - Wyd., Wrocław - Warszawa - Kraków.

Skolimowski H., 1993: Filozofia żyjąca. Wyd. Pusty Obłok, Warszawa.

Wroczyński R., 1985: Pedagogika społeczna. PWN, Warszawa.

Znaniecki F, 1928: Socjologia wychowania. Książnica, Warszawa.

Zylbertal W. H., 2000: Miejscem człowieka jest Ziemia. Wykłady z filozofii. Wydawnictwo „Zielone Brygady", Kraków.

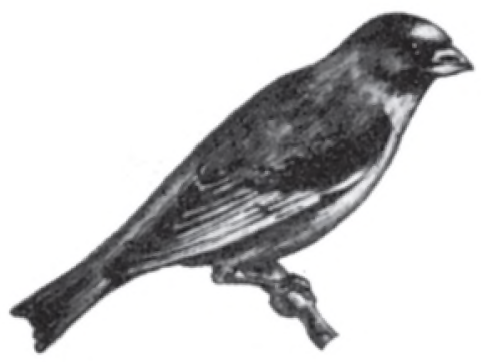

Dzwoniec 